\title{
Critical Study of the Adverse Effects of Merger of Banks in the Indian Economy
}

\author{
Rajeev Dutraj, Asst. Prof of Business Administration, Siliguri Institute of Technology, Siliguri, WB, \\ India.rdutrajclg@gmail.com
}

\begin{abstract}
When we were small, whenever we thought of saving some money, we ended up giving it to our parents. But as grown-ups, banks hit our minds the moment thoughts of saving money start spurring. But why is it so? It is because, banks are the most secure place to save our hard-earned money. A bank is a financial institution that particularly deals with deposits, advances and many other related services. The bank not only works as an institution to save money but it rather fosters the economy or hinders the same and most obvious generate employment as well.

When the economy is adversely affected by the policies of the government, it is obvious that it will either take the Indian economy to the zenith or it would hit the rock bottom. Here, our article is going to discuss how the merging of Banks has affected the Indian economy and how non-performing assets of the banks are being recovered. The aim of this paper is to probe \& investigate how merging has helped the Indian economy and the bank itself in the top 100 global lists of the economic survey.
\end{abstract}

Keywords: Indian Bank, Mergers, Employment, and Public Sector.

\section{INTRODUCTION}

A financial institution plays a crucial role in any economy, the work of the financial institution is to save all the public saving and recycle the same money in the economy by providing loans i.e. to the public, other companies, or the government itself. Mobilization of saving plays a very important role in an economy thus linking a person having surplus money with those who are in need of money. The interest generated from advances and saving is used for various purposes by the bank and the Government of India. The various financial products and services act as a help in savings and due to more savings more capital formation is possible thus increasing production of goods and services which further leads to increase in export and decreased import which helps to maintain a favorable balance of payment. So we can state that higher the volume of saving with the banks, larger the amount of advances can be done, resulting in the growth of Indian Economy.

When the companies want to take over the market share, It is found that they either increase their production or service unit in different areas to gain many footsteps or they go on understanding with other companies and merge with the similar business lines. The process of combining two or more than two companies into one is called merger. The main purpose of combing two or more businesses is to achieve synergy, a new company is greater than the sum of its parts.

In the 1960s, was the era of a merger of banks in India to bail out the weaker banks so that the government would protect the interest of the public. Thus, moving in the path of creating the largest global banks, the government gave a green signal with a formal accord of a merger of five associate banks with SBI in February 2017. The period 1969-1991 was called a post-nationalisation period. It was seen that six private banks were nationalized in 1980. In this era, 13 mergers took place mostly between public and private sector banks.

Later in March, approval of BMB was accorded by the Cabinet. During the period from 1961-1966, merger and nationalization took place, this period was called as prenationalization i.e. the government nationalised 14 private banks. Many private banks were merged to revive the economy from the poor performance of banks which manifested a successful move to fight underperforming banks.

\section{LITERATURE REVIEW}

A bank is a financial institution that particularly deals with deposits, advances and many other related services. The bank not only works as an institution to save money but it rather fosters the economy or hinders the same and most obvious generate employment as well. Mobilization of saving plays a very important role in an economy thus linking a person having surplus money with those who require money. The interest generated from advances and saving is used for the various purpose by the bank and the Government of India.

A merger is either a combination of two existing entities into one or shutting down the old entities into a new entity. They are two types of mergers: horizontal and vertical. 
Horizontal mergers occur when two similar segment businesses in the same industry combine into one. Vertical mergers occur when two-segment businesses in the same value chain or supply chain merge. The fusion of two or more enterprises through direct acquisition by one of the net assets of the other or others. In a merger, no new concern is created." Eric L.Kohler.

Malhotra R N (1986) [1] has highlighted the fact that nationalization of Indian commercial banks has brought dramatic changes in the profile of Indian banking. Banking has emerged as an effective catalytic agent of socioeconomic change. It has acquired a broad base and has also emerged as an agent of development in the rural sector. The new phase of banking will be characterized by increasing sophistication. Increased sophistication will be reflected in the introduction of modern technology and changes in the composition of bank business. Policies and specific measures are being framed to bring about all-round improvement in banking operations.

Robert M (1991) [2] The study attempts to analyze the trends in profitability, assess the operational efficiency of Public sector banks, estimated the behavioural function of profit affecting profit for individual banks and the banking industry as a whole. The study covers 14 banks nationalized in 1969. These were classified as large-scale banks, medium scale banks, and small-scale banks to make interbank comparisons. The study covers a period of 15 years from 1973 to 1987 . Herfindhal's index of concentration is used to study the performance of each unit of the system with reference to the system as a whole. The bank-wise trend in profitability showed that out of 14 banks, 12 showed a decline in profitability during this period. Operational efficiency based on manpower expenses and other expenses to total staff revealed that $\mathrm{CBI}, \mathrm{UCB}$, and DB were the highest cost-effective banks among large, medium and small banks.

Saha Gurudas (2001) [3] in study analyses the major financial parameters of Public and Private Sector Banks and highlights the strategic importance of banking cost determination and cost management. Public sector banks are unable to compete private sector banks due to poor governance. The financial performance of public sector banks is the lowest whereas that of SBI group is better in all ratios. SBI group have registered a higher growth in all the business parameters as compared to Nationalised banks but in the revenue parameters they are below nationalised banks, all private banks and foreign banks. It is indicated that public sector banks are losing its market share to private sector banks and foreign banks.

\section{OBJECTIVES}

The major objective of the paper assesses, the reason for the merger of public sectors banks into twelve major banks, the impact of merger and employment. The specific objectives of the paper are:

- $\quad$ To find out the reasons for bank mergers.

- To make a comparative analysis of pre and postmerger of banks.

- Have mergers of banks affected the mass employment?

- Will the merger of banks can increase the efficiency of bank performance?

\section{STATEMENT OF PROBLEM}

According to the International Monetary Fund (IMF), nationalization is a process by which the government takes over private assets and brings them under public ownership. In 1951, there were more than 400 commercial banks who worked under private sector. However, more than 360 banks had failed between 1947 and 1955, the trend continued through the 1950s and the first half of 1960s. This had forced Morarji Desai, the then finance minister, to launch a massive bank consolidation drive. It brought down the number of banks from 328 in 1960 to 68 in 1965.

The current situation of the bank crisis has become just an old wine in a new bottle. The sharp decline in bank shares price in connection with credit issues in the economy and lack of speed in recognition of Non-Performing Assets (NPA) are the main problems of Indian public sector banks which is an example of lack of corporate governance in a public sector bank. The banks that are considered to be the important pillars of the Indian economy, have been seen failing and showed lack of adequate performance, poor decision making due to lack of capacity to judge project quality, lack of efficient steps on NPA on the books and outright fraud and absence of fundamental corporate governance standards.

According to the Reserve Bank of India (RBI) the gross NPA in Indian banks, specifically $11.2 \%$ as in FY 18 [4]. Lack of good corporate governance in bank followed by big cases of the downfall of Air India thus adding to NPA. The two big Indian Industrialist willful defaulters $\mathrm{Mr}$ Vijay Mallaya and Mr Nirav Modi are the two clear pictures of lack of corporate governance in the Indian banks.

To cope up with the current situation and to increase the performance of Indian banks, the government has decided to merger many public sector banks. However, will the merger solve the problem of the banks? In India, banks play a major part in recruitment drive nevertheless after the merging of banks, last year, we could see a considerable decrease in the number of employees in banking sectors in India.

\section{RESEARCH METHODOLOGY}

In order to apprehended the stated objectives, the researcher utilised descriptive research design. The studies on a closer 
look validated NPA problems and the current merger of the banks using the secondary data.

This study has been done highly descriptive by nature. It describes the characteristics of the population or phenomena that is being studied. This methodology focuses more on the "what" of the research subject rather than the "why" of research subject. The methods used in this research could be observations or secondary data, panels analyzed quantitatively.

In order to study the impact in the economy after the merging of banks, a clear observation or secondary data is used. A preliminary study focused on a) status of banks and their NPA before the merger of public sector bank b) growth of economy before of public sector banks c) employment generation before the merger.

\section{SECONDARY DATA}

The foremost emphasis of our research is focused on analyzing the impact of public sector bank on NPA in the bank and its performance. It includes a) analysis of the data before analysis of the data of employment before and after bank merger.
All data are collected from various sources that include:

- Research reports, news reports, conference preceding and published articles available at both national and international levels related to bank merger and Indian economy.

- Statistical data on NPA, bank-performance, and employment collected mainly from the RBI website, Indian Bank Association, India Stat, IBPS and Ministry of National Economy.

\section{Sampling Unit}

For Secondary Data the sampling unit constitutes all the public sector bank to analyze its trend in NPA, market Cap, and employment

\section{Sampling Method}

Judgment sampling is used for the selection of public sector banks on the basis of that a high ratio of NPA in public sector banks.

\section{FINDINGS \& SUGGESTIONS}

After the merger of the bank the recapitalisation of banks are as seen;

$\begin{array}{llll}\text { PNB } & 16,000 \mathrm{cr} . & \text { IOB } & 3,800 \mathrm{cr} . \\ \text { Union Bank } & 11,700 \mathrm{cr} \text {. } & \text { Central Bank } & 3,300 \mathrm{cr} . \\ \text { BOB } & 7,000 \mathrm{cr} & \text { UCO Bank } & 2,100 \mathrm{cr} . \\ \text { Canara Bank } & 6,500 \mathrm{cr} . & \text { United Bank } & 1,600 \mathrm{cr} . \\ \text { Indian Bank } & 2,500 \mathrm{cr} . & \text { Punjab \& Sind Bank } & 750 \mathrm{cr} . \\ & & \end{array}$

\section{Business Cap}

SBI

$\mathrm{PNB}+\mathrm{OBC}+\mathrm{UBI}$

$\mathrm{BOB}+\mathrm{Vijay}+$ Dena

Canara + Syndicate

Union + Andra + Corp

Bank of India

Central Bank

Indian Overseas Bank

$\mathrm{UCO}$

Bank of Maharashtra

Punjab \& Sind Bank

\section{Recapitalisation}

PNB

16,000

Union Bank

11,700

Bank of Baroda

7,000

Canara Bank

6,500

Indian Bank

2,500

IOB

3,800

Central

3,300

2,100

1,600

United Bank

750 


\begin{tabular}{|c|c|c|c|c|c|c|c|}
\hline \multicolumn{2}{|c|}{$\begin{aligned} \text { PNB + OBC } \\
\text { +United Bank }\end{aligned}$} & \multicolumn{2}{|c|}{$\begin{array}{c}\text { Canara Bank } \\
+ \text { Syndicate Bank }\end{array}$} & \multicolumn{2}{|c|}{$\begin{array}{c}\text { Union Bank + Corp } \\
\text { + Andhra }\end{array}$} & \multicolumn{2}{|c|}{$\begin{array}{c}\text { Indian Bank } \\
+ \text { Allahabad Bank }\end{array}$} \\
\hline \multicolumn{2}{|c|}{ Total } & \multicolumn{2}{|c|}{ Total } & \multicolumn{2}{|c|}{ Total } & \multicolumn{2}{|c|}{ Total } \\
\hline Business: & $17,94 \mathrm{lac}$ & Business: & $15,20 \mathrm{lac}$ & Business: & $14,591 \mathrm{ac}$ & Business: & $8,071 \mathrm{lac}$ \\
\hline Branches : & 11,437 & Branches : & 10,342 & Branches : & 9,609 & Branches : & 6,104 \\
\hline Employees: & $1,00,649$ & Employees: & 89,885 & Employees: & 75,384 & Employees: & 42,814 \\
\hline Net NPA: & $6.61 \%$ & Net NPA: & $5.62 \%$ & Net NPA: & $6.30 \%$ & Net NPA & $4.39 \%$ \\
\hline
\end{tabular}

EMPLOYEE GENERATION BY PUBLIC SECTOR BANKS THROUGH IBPS (INSTITUTE OF BANKING PERSONNEL SELECTION) [5]

Name of Banks
Allahabad
Andhra Bank
Bank of Baroda
Bank of India
Bank of Maharashtra
Canara Bank
Central Bank
Corporation Bank
Dena Bank
IDBI Bank
India Bank
Indian Overseas Bank
Oriental Bank
PNB
Punjab \& Sind
Syndicate Bank
UCO Bank
Union Bank of India
United Bank of India
Vijay Bank

Financial Parameters

Total Business (In Cr)

Gross Advances (In Cr)

Deposits (In Cr)

Domestic Branches

Advance Branches

Deposit Branches

Employees

RoA

CRAR Capital Ratio

CET-1 Capital Ratio

Net NPA

CASA Ratio

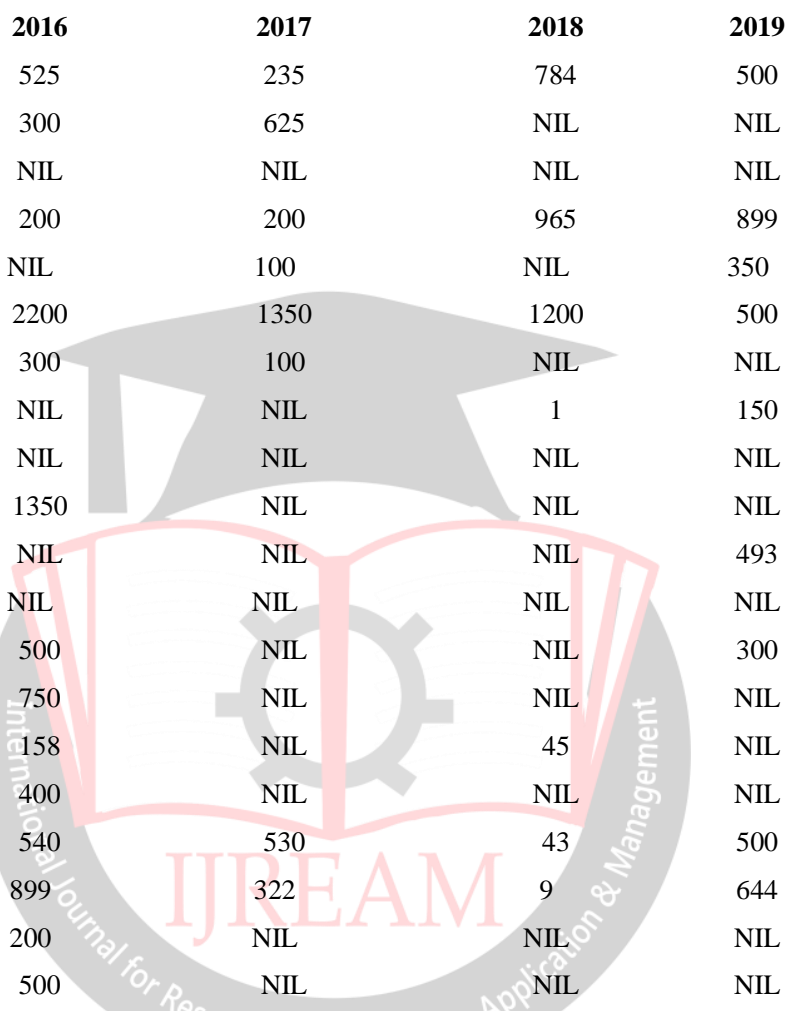

\begin{abstract}
Bank of Baroda (BoB)
\end{abstract}
h in Vijaya Bank

Dena Bank

$\begin{array}{lll}2,79,575 & 1,72,940 & 14,82,325 \\ 1,22,350 & 69920 & 6,40,600 \\ 1,57,325 & 1,03,020 & 8,41,830 \\ 2130 & 1858 & 9490\end{array}$

57

74

38

68

89

85675

15875

13440

$-0.02 \%$

$0.32 \%$

$-2.43 \%$

$12.25 \%$

$13.91 \%$

$10 \%$

$9.32 \%$

$10.35 \%$

$8.15 \%$

$5.71 \%$

$5.40 \%$

$35.52 \%$

$11.04 \%$

$34.06 \%$ 
The merger and acquisition of the banks of India help with the reduction in the cost of operation e.g. include employee compensation and benefits, information technology, surveyor etc. After merger of the banks, a single I.T department can manage three banks together, erstwhile different outsourcings were done for I.T, thus helping in reduction the operation cost of a bank.

Rural areas have become important for any business to reach out to their market share specifically in banking sectors, connecting this area has helped the government to understand and estimate the earnings or per capita income of people living in rural areas. A bank with an advance digital banking system merged with a weaker bank and with its number of branches often can help to extend its reach to the corner parts of India. At this point broadening the geographical reach through financial inclusion by bank plays a crucial role. The merging of bank has made considerable increase in the mobilization of saving thus creating a link between surplus money holders and those who are in need of money. It provides various financial product to save which in return exhilarate mobilisation of saving. Due to more saving more capital formation has or will increase production of goods and services thus leads to increase in expert and decrease in imports give on to favourable balance of payment.

When banks get merged it helps the government mitigate the burden from recapitalisation in PSBs time to time. A bigger bank can manage their capital and problem in comparison after merger which allows a bank to finance large projects. We were able to find out that larger capital by merging of banks helped in covering up the NPA of others banks.

All banks have different organisational structure and culture. Merging different banks' culture lead to reduction on the performance level due to work pressure and frustration, leading them either to switch their jobs or avail for voluntary retirement. The cost of merging of banks can't be borne by all banks. A weak merged bank reduces the bank recapitalisation value of a healthy bank.

According to my perception, merging of banks was not the only solution to be strong banks of Indian economy there are many other problems that leads to my dealt wisely such as lack of corporate governance, higher NPA and considerably weakening the employment rates in banks.

Two models could have been done those were a) privatizing two banks and monitoring them and b) employing financial specialists recruited from top management schools that means recalibrating from the recruitment process. Banks could clean up by reviving projects that can be revived after restructuring debt. Most importantly to improve the performance of the banks in India a good corporate governance and management at public sector are essential. Merging weaker banks with a stronger bank would eliminate the existence of the weaker bank, eventually leaving into one strong bank, it is better to have one strong bank than many weak banks in an economy. The merger and acquisition have many merits and demerits in its strategies so it should merge those banks having the same organisation culture and structure.

\section{CONCLUSION}

As every coin has two sides, the same goes for bank merger. It is obvious that large number does not mean that the bank can perform well or it is a yard stick to solve other problems. RBI has given a tagline to SBI, HDFC and ICICI, "too big to fail risk" - which directly implicates that these three banks can't afford to fail in India. And, if they do so, it can create a huge economic crisis in India. The merger of banks led to generation of huge number of large banks, and if any of them fail, it will create huge problem in the Indian economy.

Across the table, we can see that the banks have kept increasing their capital since 2015 and it has been a trend before that as well. But when we talk about the total business of those banks who have merged, they did not have sufficient total business, which directly affects the Indian Economy. Hence the merger was enforced to maintain the economy.

Before the merger of Punjab National Bank, Oriental Bank of Commerce and the United Bank of India, their business was

Punjab National Bank 11.82 lac.

Oriental Bank $\quad 4.04$ lac

United Bank of India 2.08 lac.

It can be seen that the total business of the United Bank was too minimum and Oriental Bank was stable enough to make the condition of both banks stable. The government merged both banks with Punjab National bank and made the business of 17.94 lac crores. To maintain the stability of Syndicate bank (Total Business 4.77 lac crore) the government merged it with Canara Bank (Total business 10.48 lac crore) and together they made the business of 15.20 lac crore.

Through the capital and business analysis, it can be noted that the merger looks like a good aid to the Indian economy because it increases the business of the banks. But, on the other side, there are still loopholes, such as, disguised unemployment, organization culture, etc. which are eagerly seeking attention of financial specialists. Nooks and crannies of such issues eventually weaken the anchor of resource bank whilst playing host to its counterparts.

The doctrinal findings of this study suggest that the strategy of merging and acquisition of Indian banks will reduce in the number of working of banks in an economy, keeping 
only 12 strong public sector banks by merging all the weak banks. It will help in reducing the operation cost of banks and increase the efficiency of the bank which can overcome the issues of piling up of non-performing assets. While doing so it can affect the recruitment and the overall organisational structure with their HR system.

However, these problems of merger of banks can be tackled with an effective management policy and adequate awareness to the employees that can play a crucial role to overcome the shortcomings.

\section{REFERENCES}

[1] Malhotra R N, "Banking Enter a New Phase", The Journal of the Institute of Bankers, Special Number: Bank Economists Conference, Vol. 57, No. 2, AprilJune 1986, pages. 94-103.

[2] Robert M, "Profitability in Public Sector Banks in India" Thesis Abstract, The Journal of Institute of Public Enterprises, Vol. 14(4), 1991, pages. 315-321.

[3] Saha Gurudas, "Financials of Indian Banking Industry and the Competitive Viability of the Public Sector Banks", The Management Accountant, Vol. 36, No. 5, May 2001, pages. 373-386

[4] https://www.ibpsguide.com/wpcontent/uploads/2019/08/CRP_PO_MT_IX.pdf

[5] https://www.businessstandard.com/article/finance/gross-npa-ratio-improvesto-9-1-at-sept-end119122400782_1.html

[6] https://economictimes.indiatimes.com/united-bank-ofindia/capitalstructure/companyid-9181.cms

[7] https://economictimes.indiatimes.com/corporationbank/capitalstructure/companyid-11804.cms

[8] https://economictimes.indiatimes.com/industry/banking /finance/banking/mega-bank-mergers-workingsmoothly-without-heartburns-bank-employeesunion/articleshow/75969850.cms

[9] www.thehindubusinessline.com

[10] https://www.oliveboard.in/blog/bank-merger-list-2019/ 